


\title{
Regional Inequality and Internal Conflict
}

\author{
Christian Lessmann
}

\author{
CESIFO WORKING PAPER NO. 4112 \\ CATEgory 6: Fiscal Policy, Macroeconomics and Growth \\ FEBRUARY 2013
}
An electronic version of the paper may be downloaded
- from the SSRN website:
- from the RePEc website:
- from the CESifo website:
wWw.SSRN.com
Www.RePEc.org
www.CESifo-group.org/wp

\section{CESifo}




\title{
Regional Inequality and Internal Conflict
}

\begin{abstract}
This paper studies the influence of interregional inequality within countries on internal conflicts. Regional inequalities are measured by the population-weighted coefficient of variation of regional GDP per capita. As the main innovation, I use a panel data set of country-level regional inequalities, which covers 56 countries (835 subnational regions) between 1980 and 2009. I also consider a broader cross-section data set for the year 2005, which covers 110 countries (1569 subnational regions). Conflict is measured by the incidence of civil war (UCDP/PRIO data) and a risk measure of internal conflict (war, terrorism, and riots) provided by the PRS Group's International Country Risk Guide. Logit estimations are employed as well as OLS fixed effects panel regressions. I find that regional inequalities increase the risk of internal conflict.
\end{abstract}

JEL-Code: D630, D740, O150, R120.

Keywords: regional inequality, internal conflict, panel data.

\author{
Christian Lessmann \\ Technical University Dresden \\ Faculty of Business and Economics \\ Chair of Public Economics \\ Germany-01062 Dresden \\ christian.lessmann@tu-dresden.de
}

This version: January 2013

I am grateful to Marcel Thum and the participants in the brown bag seminar at TU Dresden for many useful comments. 


\section{Introduction}

This paper examines the link between interregional inequalities within countries and internal conflicts.

Internal conflicts around the world produce human tragedies on a colossal scale, create humanitarian crises, and destabilize countries and regions. Internal conflicts are also a major reason for underdevelopment, at least due to the destruction of parts of the capital stock as a consequence of clashes. But importantly, for the negative economic consequences it is not necessary that a conflict break out and conflicting parties start fighting. Even the threat of conflict has negative effects, since it increases uncertainty and reduces the expected return on investment. Consequently, savings and investments slow down, and economic growth is reduced. For all of these reasons, preventing internal conflicts and reducing their intensity must be a very high policy imperative in the development agenda.

Internal conflicts are a multifaceted phenomenon. The most obvious type of internal conflict is armed civil war. According to the Correlates of War data (v4.1), the world has seen almost 250 civil wars since the end of the Second World War, with more than 2.3 million killed in action - civilian casualties not included. Terrorism is a second type of internal conflict, where one of the conflicting parties does not seek open fights, but uses single terror attacks to achieve its aims. A third type of internal conflict is civil unrest. The recent Jasmine Revolution, which flashed from Tunesia over North Africa and the Middle East, has shown the importance of this kind of internal conflict. Knowing more about the general causes of internal conflicts - in all their different types - might help to prevent them, saving lives and stimulating economic development.

One issue that has been widely neglected in the literature on the determinants of internal conflict is the role of interregional inequalities within countries. The reason is not that scholars do not expect regional inequalities to be relevant, but that data on regional inequality is very difficult to obtain. While it is quite easy to access regional data - necessary for the calculation of inequality measures - on high-income countries through the regional statistics provided by EUROSTAT or the OECD, it is hard to find appropriate data on low- and middle-income economies. However, developing countries are important for a systematic analysis of the causes of internal conflicts, since they display the most variation in the data.

The purpose of this study is to bring together recent data sets on regional inequality and internal conflict. Two data sets are used to calculate a measure of regional inequality. First, I use the regional data provided by Lessmann $(2011)$, which is 
based on subnational data on 56 countries (835 subnational regions). Regional inequalities within countries are measured by the population-weighted coefficient of variation of regional GDP per capita. The data set has a panel structure and covers the period 1980-2009. Second, I use the regional data provided by Gennaioli et al. (2012) for the calculation of similar inequality measures. This data set covers 110 countries (1569 subnational regions), but it has no time variation. Regional economic accounts refer to the year 2005. Also, different measures of internal conflict are considered. First of all, the estimations use the UCDP/PRIO conflict data in a similar way to Esteban et al. (2012a). In In addition to this, I use the variable "risk of internal conflict" provided by the PRS Group's International Country Risk Guide. This conflict measure incorporates data on civil wars, terror attacks, and riots into a combined index. I have access to the data for the period 1984-2005. The econometric analysis closely follows Esteban et al. (2012a), who study the effect of ethnicity on conflict. The important distinction is that I augment the estimation equations by the measure of regional inequality as an additional explanatory variable. Logit estimations (with clustered standard errors) are carried out, as well as OLS country fixed effects panel regressions. The estimations show that interregional inequalities increase the probability of a civil war, and similarly regional inequalities increase the risk of internal conflict. Importantly, this result is not sensitive to the definition of civil wars or to the regional data used.

This paper extends the existing literature in three directions. First and most importantly, I make use of panel data, in contrast to recent studies such as Deiwiks et al. (2012) and Buhaug et al. (2012). The major improvement is that I construct a time-varying measure of interregional inequality within countries, which is commonly used in economic geography [see, e.g., Williamson (1965) and Lessmann (2011)]. This approach allows me to control for unobserved heterogeneity between countries by considering country fixed effects. Second, interregional inequality is measured at the country level by calculating complete measures of inequality considering the whole regional distribution of income [see, e.g., Sen (1997) and Ray (1998)]. This makes the results comparable to those of studies on interpersonal inequality that use Gini coefficients or other measures of ethnicity at the country level [see, e.g., Collier and Hoeffler (2004) and Esteban et al. (2012a,b)]. Third, I consider the incidence of civil wars as well as a measure for the risk of internal conflict as dependent variables, thus combining different types of conflict. Since the risk indicator is also time-varying, this allows me to apply panel data techniques.

The reminder of the paper is organized as follows: Section 2 reviews the related

\footnotetext{
1 The conflict data is provided by a joint project of the Uppsala Conflict Data Program (UCDP) and the Peace Research Institute Oslo (PRIO) [see Harbom and Wallensteen (2010) and Gleditsch et al. (2002) for details].
} 
literature. Section 3 discusses the main variables of interest: the measure of regional inequality and the indicators of internal conflict. Section 4 presents the econometric analysis. Section 5 sums up and concludes.

\section{Interregional inequality and internal conflict}

\subsection{Theoretical literature and hypothesis}

Income inequality and other kinds of polarization are important determinants of internal conflicts in the theoretical literature. In the words of Amartya Sen: "the relationship between inequality and rebellion is indeed a close one" Sen (1973), opening page]. The underlying argument is intuitive. According to the Marxist theory, class differences between capital owners and the working class - which can be understood as economic inequalities - lead to social conflicts, rebellion, and finally the destruction of the capitalist system. However, empirical evidence on the effect of interpersonal income inequalities on conflict is not as clear cut as the theory suggests. In a review of early studies in the field, Lichbach (1989) concludes that findings on the relationship are weak and not robust. Similarly, the two perhaps most influential empirical studies in the recent conflict literature, Collier and Hoeffler (2004) and Fearon and Laitin (2003), are not able to find a significant relationship.

What are the causes of this quite puzzling empirical result on interpersonal income inequalities and conflict? In the political sciences literature, the distinction between vertical and horizontal inequalities has become a popular explanation for the inconclusiveness of empirical studies [see, e.g., Stewart (2000, 2002) and Cramer (2003)]. Vertical inequality refers to the inequalities within a group, for example a group of individuals or households. Those inequalities can be measured by the Gini coefficient of the income distribution or alternative concentration measures, which are widely used in the empirical literature. By contrast, horizontal inequality refers to inequalities between groups: ethnic groups, religious groups, races, regions, etc. These inequalities have been neglected in most cross-country studies, since they are quite difficult to measure, although they may be very important in the inequalityconflict nexus. Stewart (2000) argues that horizontal inequalities create identity, which binds the group, and are a breeding ground for grievance. In general, ethnic and religious boundaries are a powerful source of mobilization when collective action is needed to start a rebellion. If horizontal inequality is blatant between groups, mobilization becomes much more likely.

Related to this line of reasoning is the work of the economists Joan Esteban and Debraj Ray and colleagues. Esteban et al. (2012b) explain the inconclusiveness of 
the empirical studies as resulting from the opposed effects income inequality has on the risk of internal conflict. Rising inequalities are a breeding ground for resentment, making (ceteris paribus) a rebellion more likely. But at the same time, the poverty of the poor restrains them from successful insurrection, because their income is too low to purchase the necessary means. The effect of inequality on the risk of conflict is therefore ambiguous. Importantly, groups matter in this literature, too [see Esteban and Ray (1994, 2011a)]. Esteban and Ray (2011b) show that inequality between groups has an ambiguous effect on the risk of internal conflict, but withingroup inequality increases the risk of internal conflict. In addition - similarly to the reasoning by Stewart (2000) above - they show that an increase in the correlation between ethnic radicalism and inequality also increases conflict. Altogether, both strands of literature point to horizontal inequalities between groups to be decisive in the inequality-conflict nexus.

Why should interregional - or spatial - inequalities between regions matter for the risk of internal conflict? Although the evidence on the relationship between interpersonal inequality and conflict is inconclusive, this might be an indirect transmission channel, at least from a theorist's point of view. Kanbur and Venables (2005) point out that interregional inequalities are a major determinant of interpersonal inequalities. "Inequality between a nation's regions is one component of overall national inequality across individuals (the other component being of course inequality across individuals within each geographical unit or region). When spatial inequality goes up then, other things being equal, so does national inequality" Kanbur (2005), p. 11]. Therefore, one might expect that regional inequalities would fuel Marxist insurgencies through increased interpersonal - vertical - inequalities.

But interregional inequalities matter themselves, because they are by definition a type of horizontal inequalities. The arguments of Stewart $(2000,2002)$ are also applicable to subnational jurisdictions. If inequalities between groups - formed by the inhabitants of different regions within a country - increase, we should expect an increasing risk of internal conflict. Moreover, the effect should be stronger if regions are inhabited by different ethnic groups [see and Esteban et al. (2012a)]. Insofar, there is an overlap between ethnicity and regional inequality. Hechter (1975) argues that the regional income differentials stimulated the separatist mobilization of the Celtic fringe in Great Britain, while primordial nationalism was less relevant. This implies that regional inequalities might fuel nationalism of ethnic groups even if the ethnical distance between groups is small. $:^{2}$

The question arises, how interregional inequalities can affect the risk of internal

2 Ethnical distance can be understood as "alienation" in the polarization theory of Esteban and Ray (1994, 2012). 
conflict in homogeneous societies without large ethnic differences. Bolton and Roland (1997) analyze the breakup of nations in a political economy framework, where decisions in subnational regions are based on majority voting. A unified nation can realize efficiency gains (e.g., due to trade gains or economies of scale in publicgood provision), but there are costs in loss of control on political decisions - in particular with regard to redistribution policies. Bolton and Roland allow income distributions to vary across and within regions. Thus, a uniform countrywide tax rate, which finances redistribution, will almost never coincide with the tax rates preferred by the median voter of a subnational unit. If efficiency gains from unification are small, rich regions have the incentive to separate, since decentralized redistribution policies match better with the preferences of local residents [see also Oates (1972)]. A quite similar trade-off between efficiency gains from unification and political costs is stressed by Alesina and Spoalore $(1997,2003)$ in their model of the number and size of nations. Heterogeneity is introduced as geographical distance to a public good, which the authors assume to equal the distance in preferences. An increase in heterogeneity, which can be related to an increase in the heterogeneity of preferences due to a higher dispersion of incomes among regions, leads in this framework to smaller countries that can be formed through secession.

Based on the discussion of the theoretical literature, the main hypothesis of this study is:

Hypothesis 1: The risk of internal conflict increases in the level of interregional inequalities.

It is important to mention that recent theoretical and empirical findings by Esteban et al. (2012a) and Esteban et al. (2012b) suggest that ethnic polarization and fractionalization are very important in predicting the incidence of civil wars. This implies that it is necessary to control for these factors in the empirical analysis in order to separate the effects of ethnicity from those of regional inequality. Therefore,

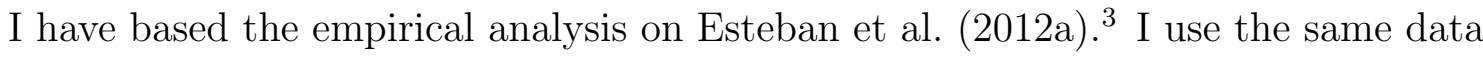
set and specifications, but I augment the estimation equation by the populationweighted coefficient of variation of regional GDP of countries.

\section{$2.2 \quad$ Related empirical literature}

In the following brief review of existing empirical literature, I focus on cross-country studies only and omit case studies on inequality and conflict, such as Hechter (1975) or Gourevitch (1979) among others. My study is also related to the literature on the

\footnotetext{
3 The data set and Stata do-files used in Esteban et al. (2012a) can be downloaded through the website of the American Economic Review: http://www.aeaweb.org/aer/data/june2012/20100805_data.zip
} 
determinants of regional inequalities, which studies for example development issues [see, e.g., Williamson (1965) and Lessmann (2011)], international trade [see, e.g., Rodríguez-Pose (2012) and Lessmann (2013)], decentralization [see, e.g., RodríguezPose and Ezcurra (2010) and Lessmann (2012)], and interregional transfers [see, e.g., Kessler et al. (2011)]. The strongest connecting element to these studies is the operationalization of interregional inequalities, which reverts to the literature on economic geography [see section 3.1 for details].

The empirical literature on inequality and conflict is extensive, although almost all studies are concerned with interpersonal income inequality [see Lichbach (1989) and Cramer (2005) for literature surveys]. Fearon and Laitin (2003) and Collier and Hoeffler (2004) are the most influential studies in the field. Neither study finds a significant effect of income inequality, measured by the Gini coefficient, on the risk of internal conflict, measured through the onset of civil war.4 However, the underlying inequality measure only considers vertical (or within-group) inequality, not horizontal inequality, which is at the heart of this analysis. As the discussion of the previous section has shown, this may be an important limitation, which recent literature has tried to overcome.

There is a growing literature on ethnicity and conflict. While the initial studies by Fearon and Laitin (2003) and Collier and Hoeffler (2004) do not find significant effects of the degree of ethnolinguistic fractionalization on the onset of civil wars, Esteban et al. (2012a, 2012b) show that this result is related to measurement difficulties. The problem is that the degree of ethnic fractionalization increases monotonically in the number of groups, but the theoretical model by Esteban and Ray (2011a) implies that group size matters, too. The level of conflict is a function of ethnic fractionalization, polarization, and inequality. The theory is confirmed by Esteban et al. (2012a,b) insofar as horizontal inequalities between ethnic groups matter in predicting internal conflicts [see also Østby (2008)]. Note that regional economic inequalities overlap to some extent with ethnic fractionalization $(F)$, polarization $(P)$, and ethnic difference $(G / N)$, but are still distinct from them. The correlation between the ethnicity measures used in Esteban et al. (2012a) and the population-weighted coefficient of variation of regional GDP per capita ( $W C V$ ) calculated based on Gennaioli et al. (2012) is summarized by Table 1. The ethnicity and inequality measures are positively correlated with regional inequalities. The strongest correlation is between the degree of ethnolinguistic fractionalization and regional inequalities, implying that countries with many different ethnic groups are

\footnotetext{
${ }^{4}$ Both studies build upon the Correlates of War (COW) data set Doyle and Sambanis (2000)], but they differ, for example, with regard to the inclusion of anticolonial wars. Data on interpersonal inequality comes from Deininger and Squire (1996).
} 
Table 1: Correlation: fractionalization, polarization, ethnic difference, and regional inequality

\begin{tabular}{lrrrr}
\hline Variable & $P$ & $F$ & $G / N$ & $W C V$ \\
\hline$P$ & 1.00 & & & \\
$F$ & 0.21 & 1.00 & & \\
$G / N$ & 0.48 & 0.15 & 1.00 & \\
$W C V$ & 0.17 & 0.22 & 0.04 & 1.00 \\
\hline
\end{tabular}

also heterogeneous with respect to differences in regional economic performance. However, the correlation is not very high, implying that regional inequalities are different. This is an outcome of (economic) geography, terrain, endowment with point resources in one or more subnational regions, etc. As mentioned in the previous section, I therefore take the empirical framework of Esteban et al. (2012a) as the starting point for my empirical analysis in order to separate the effects of ethnicity and regional inequality.

The first study which focuses explicitly on regional inequalities is Østby et al. (2009). The authors study 22 sub-Saharan countries between 1986 and 2004. The dependent variable is the onset of civil war at the subnational level as reported by the UCDP/PRIO Armed Conflict Dataset. Regional inequalities are considered by the regional relative deprivation $(\mathrm{RRD})$ in household assets $5^{5}$ The source information comes from the Demographic and Health Surveys. Since single observations of the inequality measure are correlated within countries, the authors estimate a logit model with standard errors clustered at the country level. The study reveals that absolute welfare decreases the risk of internal conflict at the regional level, while the regional relative deprivation has no significant effect, if a linear relationship is considered. However, when considering a nonlinear relationship - by adding a squared term in the RRD to the regression - the authors find a curvilinear effect: only the poorest regions in the data set have an increased probability for the onset of a civil war. In light of this, the study supports the hypothesis that vertical inequalities have an effect on the risk of internal conflict, although the results do not seem to be very robust.

An also related study is Deiwiks et al. (2012), which focuses on regional inequality and conflict in federations. Based on the regions of 31 countries covering the period 1991-2005, they find that regions which are rich or poor compared to the country mean have a higher likelihood to engage in secessionist conflict. It is important to note that the empirical design of this study is very different to mine, in particular

\footnotetext{
${ }^{5}$ The RRD is calculated as follows: $\mathrm{RRD}=-1\left(\ln \left[\sum_{i}^{M} \frac{A_{i 1} / A_{i 2}}{M}\right]\right)$, where $M$ is the maximum of household assets, $A_{1}$ refers to the mean asset score of a given region $i$, and $A_{2}$ is the corresponding mean score of the country as a whole.
} 
in three dimensions: (1) the underlying regional data, (2) the inequality measure as the main variable of interest, and (3) the estimation method. Ad (1): In Deiwiks et al. (2012) the inequality measure is based on estimates of regional GDP based on the gridded output provided by the G-Econ Database. ${ }^{6}$ The data is available only for one year (1990); therefore the resulting data set has no panel structure. This makes panel fixed effects analysis impossible, and an omitted-variables analysis might produce an endogeneity bias in the estimates. Using the regional data provided by Lessmann (2011) overcomes this problem. Ad (2): Another important difference is that my approach uses complete measures of inequality such as the population-weighted coefficient of variation, while Deiwiks et al. (2012) rely on the disaggregated relative income differences between a particular region and the country average.7 Importantly, relative differences do not take the whole distribution of incomes into account, and they do not satisfy the Pigou-Dalton principle [see Sen (1973) and Mehran (1976)]. Moreover, the different size of subnational units, in particular as represented by the regional population, is not taken into account in this approach. Ad (3): Deiwiks et al. (2012) explain deviations of regional GDP from the country mean in a pooled cross section of regions $\square^{8}$ while I explain regional inequality at the country level. This makes my analysis comparable to cross-country studies such as Fearon and Laitin (2003), Collier and Hoeffler (2004), and Esteban et al. (2012a,b).

However, although the design of the cross-country studies on interregional inequality and conflict - Østby et al. (2009), Deiwiks et al. (2012), and this one - is very different in several dimensions, the finding is quite similar. Interregional (horizontal) inequalities increase the risk of internal conflict within countries. This may be an important reason for the unstable results of existing studies on inequality and conflict, which focus on interpersonal (vertical) inequality.

\footnotetext{
${ }^{6}$ The authors calculate the gross regional product product per capita based on the gridded output provided by the G-Econ Database [see Nordhaus (2006) and Nordhaus et al. (2006) for details of the G-Econ Database]. Gridded output means output per unit area, where the terrestrial cell has dimensions 1 degree of latitude and 1 degree of longitude. A problem with the geo-coded data is that the accuracy varies widely among countries [see Nordhaus (2006), p. 3511]. While many different sources of regional economic and demographic data (regional employment, regional gross value added, regional employment by industry, etc.) are used to calculate gridded output in highincome countries such as the United States or Canada, output per unit of area in developing countries such as Nigeria is calculated only based on population census data and employment data - no differences in productivity are taken into account. Therefore the data quality varies with the (different) sources of regional data available, which may result in a bias.

${ }^{7}$ Regional inequality (lineq2) is calculated as follows: line $2=\left[\log \left(y_{j, i} / \bar{y}_{i}\right)\right]^{2}$, where $y_{j, i}$ is the (estimated) regional GDP of region $j$ in country $i$, and $\bar{y}_{i}$ is the average GDP in country $i$.

${ }^{8}$ An econometric problem in the approach of Deiwiks et al. (2012) is that the single observations (deviation of regional GDP from country mean) are not independent from each other, since the are linked through the common country mean. Due to this violation of the i.i.d. assumption, the authors use clustered standard errors. As Rogers (1993) and Kézdi (2004) demonstrate, standard errors are downward biased if the number of clusters (here countries) is smaller than 50 .
} 


\section{Data}

\subsection{Regional inequality}

The main explanatory variable in the forthcoming empirical analysis is the level of regional inequality within countries. This paper makes use of two different data sets. In general, international databases - such as the OECD Regional Statistics and the EUROSTAT Territorial Database - only provide regional economic accounts for highly developed countries, which is a serious drawback for our research question. We need regional economic accounts also for less-developed countries.

The first source of data is provided by Lessmann (2011), who collects data from national statistical offices and central banks upon individual request, in addition to publicly available data sources. Using these regional accounts, I calculate the weighted coefficient of variation ( $W C V$ ) of regional GDP per capita, which is widely used in the literature on regional inequality [see, e.g., Williamson (1965)]:

$$
W C V:=\frac{1}{\bar{y}}\left[\sum_{i=1}^{n} p_{i}\left(\bar{y}-y_{i}\right)^{2}\right]^{1 / 2} .
$$

Here, $\bar{y}$ is the country's average GDP p.c., $y_{i}$ is the GDP p.c. of region $i, p_{i}$ is the share of the country's total population in region $i$, and $n$ is the number of spatial units. The advantages of this measure are that it is mean-independent, independent of the sizes and the number of spatial units, and robust against single extreme observations. Moreover, it satisfies the Pigou-Dalton transfer principle [Dalton (1920), Pigou (1912)], which states that a transfer from rich to poor regions should reduce the inequality measure [see Sen (1973) and Mehran (1976) for details] ${ }^{9}$ Concerning the territorial level, Lessmann (2011) refers to regional data based on the OECD TL2 or NUTS2 level for OECD member countries, and on state- or province-level data otherwise 10

Based on Lessmann (2011), I have calculated the weighted coefficient of variation using the regional GDP p.c. for 51 countries covering the period 1980-2009. Note that the frequency of the data varies by country: the underlying panel is almost balanced for OECD countries, but there are quite large gaps in the data for developing countries. Table 2 presents the means of these calculations for the most recent years, 2000-2009, subdivided by the different regions of the world following the standard

\footnotetext{
9 Other inequality measures such as the (log of the) standard deviation of regional GDP p.c., which are commonly used in the literature on growth and convergence [see, e.g., Barro and Sala-i-Martin (1992), Sala-i-Martin (1996)], are less appropriate in our context, since they cannot take account of the heterogeneity of regions with respect to population size. Also, the Theil index is not applicable for cross-section analysis with large variations in the number of subnational units of the countries considered, since its values range from 0 to $\ln n$ [Hale (2003)].

10Note that I use NUTS3-level data in those countries, where NUTS2 data is not reported.
} 
World Bank classification.

Table 2: Population-weighted coefficient of variation of regional GDP p.c. based on Lessmann (2011)

\begin{tabular}{|c|c|c|c|}
\hline Country & $W C V$ & Country & $\overline{W C V}$ \\
\hline \multicolumn{2}{|c|}{ Europe and Central Asia } & \multicolumn{2}{|l|}{ North America } \\
\hline Austria & 0.20 & Canada & 0.16 \\
\hline Belgium & 0.35 & United States of America & 0.17 \\
\hline Bulgaria & 0.29 & & \\
\hline Croatia & 0.21 & \multicolumn{2}{|c|}{ Latin America and Caribbean } \\
\hline Czech Republic & 0.39 & Bolivia & 0.29 \\
\hline Denmark & 0.11 & Brazil & 0.48 \\
\hline Finland & 0.17 & Chile & 0.35 \\
\hline France & 0.29 & Colombia & 0.46 \\
\hline Germany & 0.20 & Mexico & 0.59 \\
\hline Gerogia & 0.19 & Panama & 0.46 \\
\hline Greece & 0.13 & Peru & 0.42 \\
\hline Hungary & 0.40 & & \\
\hline Ireland & 0.17 & \multicolumn{2}{|l|}{ East Asia and Pacific } \\
\hline Italy & 0.27 & Australia & 0.09 \\
\hline Kazakhstan & 0.75 & Indonesia & 0.89 \\
\hline Latvia & 0.53 & Japan & 0.13 \\
\hline Lithuania & 0.30 & Korea, Rep. (South) & 0.06 \\
\hline Netherlands & 0.14 & Mongolia & 0.67 \\
\hline Norway & 0.32 & New Zealand & 0.07 \\
\hline Poland & 0.25 & Philippines & 0.62 \\
\hline Portugal & 0.25 & Thailand & 0.88 \\
\hline Romania & 0.39 & & \\
\hline Russian Federation & 0.37 & \multicolumn{2}{|l|}{ South Asia } \\
\hline Slovak Republic & 0.46 & India & 0.42 \\
\hline Slovenia & 0.18 & & \\
\hline Spain & 0.21 & \multicolumn{2}{|l|}{ Sub-Sahara Africa } \\
\hline Sweden & 0.21 & South Africa & 0.41 \\
\hline Switzerland & 0.20 & Tanzania & 0.37 \\
\hline Turkey & 0.43 & & \\
\hline Ukraine & 0.58 & & \\
\hline United Kingdom & 0.37 & & \\
\hline
\end{tabular}

The numbers suggest a link between regional inequality and development. Highincome countries in the core of Europe, Scandinavia, and North America have much lower regional inequalities than low- and middle-income countries. But there are also interesting variations within the different country groups; for example, among the European countries the United Kingdom and Belgium have quite high spatial inequalities, while Denmark and the Netherlands are much more homogeneous. 
The second source of regional data is provided by Gennaioli et al. (2012). The underlying data sources have some overlap with Lessmann (2011), but the territorial level is more heterogeneous. While Lessmann (2011) focuses on subnational units as defined by the OECD or EUROSTAT classifications, Gennaioli et al. (2012) focus on those subnational units which have the highest political autonomy. Another difference is that Lessmann (2011) uses only the regional GDP per capita, while Gennaioli et al. also consider wages and household income data as proxy for the level of regional development. The data set provided by Gennaioli et al. (2012) covers regional economic accounts of 110 countries for the year 2005, of which 98 can be used in the analysis. The population-weighted coefficient of variation based on this data set is reported in Table 3 .

A closer look at the numbers shows that the results are quite similar to those for the data set provided by Lessmann (2011). The correlation of the inequality measures between the different data sets is 0.78. Both data sets have their pros and cons. The advantage of the data set based on Lessmann (2011) is the panel structure, but it does not cover many low-income countries, in particular those from sub-Sahara Africa. That is the major advantage of the data set based on Gennaioli et al. (2012), which has the disadvantage of yielding no time variation. Due to these important differences, I make use of both data sets in the forthcoming econometric analysis. 
Table 3: Population-weighted coefficient of variation of regional GDP p.c. based on Gennaioli et al. (2012)

\begin{tabular}{|c|c|c|c|c|c|}
\hline Country & $W C V$ & Country & $W C V$ & Country & $W C V$ \\
\hline \multicolumn{2}{|c|}{ Europe and Central Asia } & \multicolumn{2}{|c|}{ South Asia } & \multicolumn{2}{|c|}{ Middle East and North Africa } \\
\hline Albania & 0.50 & India & 0.44 & Egypt & 0.33 \\
\hline Armenia & 0.19 & Nepal & 0.17 & Iran & 0.63 \\
\hline Austria & 0.22 & Pakistan & 0.08 & Israel & 0.12 \\
\hline Azerbaijan & 0.12 & Sri Lanka & 0.50 & Jordan & 0.20 \\
\hline Belgium & 0.36 & & & Lebanon & 0.24 \\
\hline Bosnia and Herz. & 0.09 & \multicolumn{2}{|c|}{ East Asia and Pacific } & Morocco & 0.23 \\
\hline Bulgaria & 0.24 & Australia & 0.09 & Syrian Arab Rep. & 0.11 \\
\hline Croatia & 0.34 & Cambodia & 0.38 & United Arab Em. & 0.44 \\
\hline Czech Republic & 0.40 & China & 0.54 & & \\
\hline Denmark & 0.24 & Indonesia & 0.87 & \multicolumn{2}{|c|}{ North America } \\
\hline Estonia & 0.42 & Japan & 0.30 & Canada & 0.21 \\
\hline Finland & 0.16 & Korea, Rep. & 0.22 & United States & 0.17 \\
\hline France & 0.26 & Lao PDR & 0.32 & & \\
\hline Georgia & 0.19 & Malaysia & 0.38 & \multicolumn{2}{|c|}{ Sub-Sahara Africa } \\
\hline Germany & 0.20 & Mongolia & 0.57 & Benin & 0.50 \\
\hline Greece & 0.29 & New Zealand & 0.19 & Burkina Faso & 0.13 \\
\hline Hungary & 0.41 & Philippines & 0.25 & Cameroon & 0.30 \\
\hline Ireland & 0.17 & Thailand & 0.87 & Congo, Dem. Rep. & 0.85 \\
\hline Italy & 0.26 & Vietnam & 0.33 & Gabon & 0.24 \\
\hline Kazakhstan & 0.30 & & & Ghana & 0.38 \\
\hline Kyrgyz Republic & 0.49 & \multicolumn{2}{|c|}{ Latin America and Caribbean } & Kenya & 0.91 \\
\hline Latvia & 0.59 & Argentina & 0.73 & Lesotho & 0.35 \\
\hline Lithuania & 0.31 & Belize & 0.26 & Madagascar & 0.32 \\
\hline Macedonia, FYR & 0.45 & Bolivia & 0.36 & Malawi & 0.12 \\
\hline Moldova & 0.29 & Brazil & 0.48 & Mozambique & 1.01 \\
\hline Netherlands & 0.14 & Chile & 0.36 & Namibia & 0.72 \\
\hline Norway & 0.35 & Colombia & 0.38 & Niger & 0.42 \\
\hline Poland & 0.26 & Dominican Rep. & 0.32 & Nigeria & 0.43 \\
\hline Portugal & 0.26 & Ecuador & 0.29 & Senegal & 0.16 \\
\hline Romania & 0.40 & El Salvador & 0.28 & South Africa & 0.44 \\
\hline Russia & 0.93 & Guatemala & 0.47 & Swaziland & 0.21 \\
\hline Serbia & 0.39 & Honduras & 0.44 & Tanzania & 0.35 \\
\hline Slovak Republic & 0.53 & Mexico & 0.58 & Uganda & 0.30 \\
\hline Slovenia & 0.26 & Nicaragua & 0.36 & Zambia & 0.34 \\
\hline Spain & 0.20 & Panama & 0.48 & Zimbabwe & 0.32 \\
\hline Sweden & 0.21 & Paraguay & 0.29 & & \\
\hline Switzerland & 0.27 & Peru & 0.47 & & \\
\hline Turkey & 0.34 & Uruguay & 0.37 & & \\
\hline Ukraine & 0.57 & Venezuela & 0.29 & & \\
\hline United Kingdom & 0.22 & & & & \\
\hline Uzbekistan & 0.43 & & & & \\
\hline
\end{tabular}




\section{$3.2 \quad$ Internal conflict}

The main response variable in the econometric analysis is the incidence of civil war. In that respect, I follow closely Esteban et al. (2012a). I use the most recent conflict data provided jointly by the Uppsala Conflict Data Program and the Peace Research Institute Oslo [UCDP/PRIO Armed Conflict Dataset v.4-2010, 1946-2009; see Harbom and Wallensteen (2010) and Gleditsch et al. (2002)]. Armed conflicts are defined as follows:

An armed conflict is defined [...] as a contested incompatibility that concerns government or territory or both, where the use of armed force between two parties results in at least 25 battle-related deaths in a year. Of these two parties, at least one has to be the government of a state. The incompatibility is the stated (in writing or verbally) generally incompatible positions [Harbom and Wallensteen (2010), p. 508].11

The intensity of conflicts is considered by classifying the data into three categories: (1) armed conflicts, with at least 25 battle-related deaths per year and per incompatibility (PRIO25); (2) intermediate armed conflicts, which include armed conflicts with a minimum of 1,000 deaths over the course of the conflict (PRIOCW); (3) wars, with a threshold of battle-related deaths of at least 1,000 per year and per incompatibility (PRIO1000). In the analysis, a country is coded as having experienced a conflict in a given period if, in any of the years within this period, the corresponding threshold condition has been met. I mainly focus on armed conflicts (PRIO25) and use the alternative classifications for robustness tests. Note that I also provide robustness tests using alternative - not binary-coded - conflict variables [see section 4.4 for details]. As Esteban et al. (2012a) point out, this conflict measure is different to the onset of civil wars, which reflects whether a fresh conflict breaks out in the period of observation.

The incidence of conflict varies for the different regional data sets used, which results in different country samples. In the estimations which use the data provided by Gennaioli et al. (2012), there are 207 country-period pairs with an armed conflict (PRIO25) within a total of 876 observations of 5-year period averages of 98 countries. That is a share of conflict periods of $24 \%$. The incidence of conflict is lower in the sample of countries covered by Lessmann (2011), where I count 38 conflicts within 196 observations (19\%). However, internal conflicts are a quite common phenomenon in both country samples.

${ }^{11} \mathrm{~A}$ more detailed definition can be found on UCDP's webpage, at http://www.ucdp.uu.se. 
The binary conflict variables have two important drawbacks. First, they do not vary much over time, in particular in highly developed countries that have experienced very few conflicts since the end of the Second World War. Second, the variables capture only those conflicts which involve government troops in open fights. However, as mentioned in the introduction, this is just one dimension of internal conflicts. One conflicting party might also choose to engage in terror attacks or to organize riots in order to achieve its aims.

Therefore, I also consider the variable "risk of internal conflict" provided by the PRS Group's International Country Risk Guide (ICRG). I have access to the data for the period 1984-2005. The index is created from an annual survey of experts who rate a country's risk of conflict in three categories: civil war and coup threat, terrorism and political violence, and civil disorder. The highest rating is given to those countries where there is no armed or civil opposition to the government and the government does not indulge in arbitrary violence, direct or indirect, against its own people. The lowest rating is given to a country embroiled in an ongoing civil war. The risk rating assigned is the sum of the three subcomponents, each with a maximum score of 4 points and a minimum score of 0 points. A score of 4 points equates to very low risk, and a score of 0 points to very high risk. Thus, the index ranges from 0 to 12 , and the highest score indicates no risk of internal conflict. I have rescaled the index in such a manner that the highest value is given to the countries with the highest risk of internal conflict, to make interpretation of results easier.

One advantage of the risk data is that the surveyed country experts rate the risk of conflict gradually, the threat of a conflict being already taken into consideration. This is an important feature for the economic consequences. The increasing risk of civil wars, terrorist attacks, and civil disorder will discourage investments. Investors are afraid of expropriation and deterioration of the physical capital in the conflicting countries. As a result, the capital stock and economic growth will be lower, the higher the risk of conflict. For this to happen, it is not necessary that an armed conflicts should break out. But nothing comes without a cost. The risk of internal conflict might also react on international terrorism, which can produce variation in the data which cannot be explained through standard determinants of internal conflict. Moreover, the data is not as objective as the binary civil war data, since the country risk ratings are based on expert surveys.

To give a first impression of the data, Table 4 shows the five countries with the highest and the five with the lowest risk of internal conflict in the last year of the observation period (2005). Note that I only consider those countries where I have regional accounts in at least one of the two data sources. The data shows 
no surprises: the Democratic Republic of Congo was the country with the highest risk of internal conflict, and Switzerland the country with the lowest. Concerning volatility of the risk of internal conflict, El Salvador, Lebanon, and the United Arab Emirates are the countries with the highest standard deviation of the ICRG index, while Switzerland, Norway, and Moldova had the lowest. In this respect, Switzerland is an extreme observation, since only in the year 2002 was its ICRG index not at the highest possible value. All other countries show more variation over time.

Table 4: Risk of internal conflict of sample countries in 2005

\begin{tabular}{lclc}
\hline & High risk Top 5 & & Low risk Top 5 \\
& ICRG index & & ICRG index \\
Country & 2005 & Country & 2005 \\
\hline Congo & 6.79 & Switzerland & 0.00 \\
Colombia & 6.21 & Sweden & 0.50 \\
Pakistan & 6.00 & Norway & 0.50 \\
Sri Lanka & 5.63 & New Zealand & 0.50 \\
Nigeria & 5.50 & Lithunia & 0.50 \\
\hline
\end{tabular}

\section{Empirical model}

I parse my research question by estimating variants of different panel data models. The data and econometric methodology are similar to Esteban et al. (2012a). The basic regression for $N$ countries and $T$ time periods, where countries are indexed by $i$ and time by $t$, has the following form:

$$
C_{i, t}=\sum_{k=1}^{q} \beta_{k} X_{k, i, t}+\gamma W C V_{i, t}+\epsilon_{i, t},
$$

where $C_{i, t}$ is the incidence of armed internal conflict, $X_{k, i, t}$ represents $q$ different control variables, $W C V_{i, t}$ is the population-weighted coefficient of variation of the regional GDP per capita as measure for the level of regional inequality, and $\epsilon_{i, t}$ is a random error term. The main coefficient of interest is $\gamma$, which I expect to be positive. In the literature on the determinants of civil wars there is an ongoing controversy about whether to use annual data or period-averaged data [see Collier and Hoeffler (2004) and Fearon (2005)]. I follow Esteban et al. (2012a) and calculate 5 -year period averages covering the period 1960-2009. The binary conflict variable is assigned the value 1 if an internal conflict was observed in one of the 5 years of a period. 
I make use of two different data sets of regional economic accounts and two different measures of conflict. The inequality measures calculated based on Lessmann (2011) are time-varying, as is the risk of internal conflict from the International Country Risk Guide. Therefore, I can also consider a panel fixed effects model. Using country fixed effects reduces a potential endogeneity bias of the estimates caused by omitted (country-specific, unobservable) variables. The historical background of a country (e.g., its colonial past), its past experience in external wars, and its geography are examples of such unobservable factors. Using country fixed effects eliminates the unobserved heterogeneity between countries, thereby reducing this potential source of bias.

In the following, I estimate logit models as well as ordinary least squares (OLS) models. Logit estimates are carried out where I use the binary conflict data from PRIO as dependent variable. Note that I use the same data set and the Stata do-files provided by Esteban et al. (2012a), augmenting the estimation equation with the measure of regional inequality (and some other geographic controls discussed later) as additional explanatory variable. OLS regressions are carried out where I use the risk of internal conflict as a dependent variable combined with country fixed effects. Concerning the selection of control variables, I follow Esteban et al. (2012a). Thereby, I consider the population size, the GDP per capita, the natural resource endowment, geographic variables, and institutional variables. Most importantly, the incidence of civil war and the risk of internal conflict are deeply affected by past realizations of the respective measure, so I use lagged conflict as an additional control in all specifications. The detailed definitions and data sources of all variables considered in the econometric analysis are provided by Table A.1 in the appendix. Summary statistics are provided by Table A.2 in the appendix.

First, I present regression results using the inequality measures based on Lessmann (2011): section 4.1 presents the results of logit estimations using the PRIO data as dependent variable; section 4.2 presents results of fixed effects OLS estimations using the ICRG index "risk of internal conflict". Second, I present regression results using the regional accounts provided by Gennaioli et al. (2012), which increases the number of countries significantly, but the measure of regional inequality does not vary over time: section 4.3 presents logit estimates using the PRIO data; section 4.4 presents estimations with alternative conflict measures as robustness check.

To get a first impression of how regional inequality affects internal conflict, I have calculated the mean of the measure of regional inequality within the country-period pairs with and without an armed conflict. In the group of observations with an armed conflict, the population-weighted coefficient of variation is on average 0.41 , while it 
is 0.33 in the group of observations without conflict. A quite similar result can be obtained if the measure of regional inequality is plotted against the ICRG index "risk of internal conflict". Figure 1 shows a scatterplot using the regional inequality measures based on Lessmann (2011). The figure suggests a positive correlation, i.e.,



Figure 1: Regional inequality and risk of internal conflict

the higher the regional inequalities within countries, the higher is the risk of internal conflict.

\subsection{Baseline estimates with PRIO25}

The baseline results are presented in Table 77. There I reproduce the estimations presented in Table 1 of Esteban et al. (2012, p. 1319), adding the level of regional inequalities within countries as an additional explanatory variable. Regional inequalities are calculated based on Lessmann (2011). The sample consists of 51 countries and covers the period 1980-2009. In all cases, I compute robust standard errors adjusted for clustering at the country level.

Each column in the table contains a specification of equation (2), where I progressively add control variables. Column 1 uses the population and the different distributional indices considered by Esteban et al. (2012a) as control variables. The distributional indices are ethnic polarization $(P)$, fractionalization $(F)$, and the Greenberg-Gini index $(G / N)$ [see Esteban and Ray (2011a) for details]. Column 2 adds in lagged conflict. Column 3 adds in the GDP per capita. Column 4 considers a dummy for whether a country produces oil and/or diamonds. Column 5 factors 
Table 5: Baseline specification with PRIO25, Fearon groupings

\begin{tabular}{|c|c|c|c|c|c|c|c|}
\hline & \multicolumn{7}{|c|}{ Dependent variable: incidence of civil war (PRIO25) } \\
\hline & (1) & (2) & (3) & (4) & (5) & (6) & (7) \\
\hline \multirow[t]{2}{*}{$P$} & 5.42 & 4.47 & 4.21 & 4.25 & -8.91 & -7.34 & 27.67 \\
\hline & $(0.55)$ & $(0.80)$ & $(0.78)$ & $(0.76)$ & $(-0.93)$ & $(-0.59)$ & $(1.18)$ \\
\hline \multirow[t]{2}{*}{$F$} & $3.44^{*}$ & $2.30^{*}$ & $2.33^{*}$ & 2.27 & $6.20^{* *}$ & $5.87^{*}$ & $10.55^{* * *}$ \\
\hline & $(1.80)$ & $(1.74)$ & $(1.78)$ & $(1.33)$ & $(2.05)$ & $(1.80)$ & $(3.51)$ \\
\hline \multirow[t]{2}{*}{$G / N$} & -3.77 & 18.12 & 20.87 & 20.97 & $76.00^{*}$ & 67.02 & -68.59 \\
\hline & $(-0.12)$ & $(0.88)$ & $(0.94)$ & $(0.94)$ & $(1.96)$ & $(1.26)$ & $(-1.25)$ \\
\hline \multirow[t]{2}{*}{$R E G I N E Q$} & $3.12^{*}$ & 2.43 & 2.75 & 2.75 & $32.94^{* * *}$ & $30.68^{* *}$ & $44.05^{* *}$ \\
\hline & (1.83) & $(0.97)$ & $(0.89)$ & $(0.89)$ & $(3.10)$ & $(2.26)$ & (1.97) \\
\hline \multirow[t]{2}{*}{$P O P$} & $0.71^{* * *}$ & $0.70 * * *$ & $0.71^{* * *}$ & $0.70^{* *}$ & -0.29 & -0.22 & 0.06 \\
\hline & $(2.89)$ & $(3.06)$ & $(3.15)$ & $(2.56)$ & $(-0.53)$ & $(-0.36)$ & $(0.03)$ \\
\hline \multirow[t]{2}{*}{$G D P P C$} & & & 0.13 & 0.13 & -1.37 & -1.51 & -3.56 \\
\hline & & & $(0.26)$ & $(0.25)$ & $(-1.13)$ & $(-1.22)$ & $(-0.63)$ \\
\hline \multirow[t]{2}{*}{$O I L / D I A M$} & & & & 0.05 & 1.99 & 1.90 & 3.03 \\
\hline & & & & $(0.05)$ & $(1.26)$ & $(1.21)$ & $(1.53)$ \\
\hline \multirow[t]{2}{*}{$M O U N T$} & & & & & $0.24^{* * *}$ & $0.23^{* *}$ & $0.19^{*}$ \\
\hline & & & & & $(3.38)$ & $(2.51)$ & $(1.82)$ \\
\hline \multirow[t]{2}{*}{ NCONT } & & & & & $16.42^{* * *}$ & $15.36^{* *}$ & 22.73 \\
\hline & & & & & $(3.11)$ & $(2.31)$ & $(1.58)$ \\
\hline \multirow[t]{2}{*}{$D E M O C$} & & & & & & 0.80 & 0.70 \\
\hline & & & & & & $(0.26)$ & $(0.28)$ \\
\hline \multirow[t]{2}{*}{$E X C O N S$} & & & & & & & $-5.04 *$ \\
\hline & & & & & & & $(-1.86)$ \\
\hline \multirow[t]{2}{*}{$A U T O C R$} & & & & & & & $-31.28^{* * *}$ \\
\hline & & & & & & & $(-5.17)$ \\
\hline \multirow[t]{2}{*}{ POLRIGHTS } & & & & & & & 30.80 \\
\hline & & & & & & & $(-)$ \\
\hline \multirow[t]{2}{*}{$C I V L I B$} & & & & & & & $3.429^{* *}$ \\
\hline & & & & & & & $(1.98)$ \\
\hline \multirow{2}{*}{$L A G$} & & $4.41^{* * *}$ & $4.42^{* * *}$ & $4.42^{* * *}$ & $2.07^{* *}$ & $2.09^{* *}$ & 0.82 \\
\hline & & $(5.90)$ & $(5.82)$ & $(5.73)$ & $(2.36)$ & $(2.35)$ & $(0.78)$ \\
\hline \multirow[t]{2}{*}{ CONST } & $-16.36^{* * *}$ & $-17.26^{* * *}$ & $-18.84^{* *}$ & $-18.64^{* *}$ & -14.09 & -12.94 & -10.31 \\
\hline & $(-3.87)$ & $(-4.42)$ & $(-2.49)$ & $(-2.19)$ & $(-1.16)$ & $(-1.04)$ & $(-0.74)$ \\
\hline Pseudo- $R^{2}$ & 0.36 & 0.66 & 0.66 & 0.66 & 0.77 & 0.77 & 0.83 \\
\hline Observations & 196 & 194 & 194 & 194 & 194 & 194 & 194 \\
\hline$N$ & 51 & 51 & 51 & 51 & 51 & 51 & 51 \\
\hline
\end{tabular}

in geographical controls, which are quite important in my model. Regional income inequalities are closely related to geographic features such as mountains, deserts, coasts, endowment with point resources, etc. At the same time, geography has also a direct effect on the risk of conflict, since insurgency is favored by rough terrain and a noncontiguous territory [see Fearon and Laitin (2003)]. Column 6 brings in the standard political control for democracy. Column 7 adds in more political and governance controls.

Throughout, the coefficient of the indicator of regional inequalities is positive as expected. The effect is statistically significant in the specifications reported in columns $1,5,6$, and 7 . Obviously, the consideration of geographic controls is very import- 
ant, as indicated by the results reported in column 5 . Here, the effect of regional inequalities becomes highly significant. This result is robust to the inclusion of the political controls (columns 6 and 7 ). The population size is positively associated with conflict in some of the specifications. Lagged conflict is positive and highly significant. The GDP per capita has no effect in this sample of countries, which is biased towards highly developed countries. Similarly, natural resources have no significant effect on conflict. Finally, in line with Esteban et al. (2012a), the effect of ethnic fractionalization is positive and significant. However, the other ethnic variables have no robust effects, which is again related to the different country sample. Note that the results of Esteban et al. (2012a) will be confirmed in the broader data set used in section 4.3. I conclude from these estimations that interregional inequalities increase the probability of armed conflicts, in support of the hypothesis stated in section 2.1

As a robustness check, I have also considered lagged values of the measure of regional inequality instead of contemporaneous values. It is reasonable to expect that the GDP per capita of subnational regions involved in a conflict will be lower during the course of conflict. Therefore, regional inequalities may also be affected by internal conflicts. The sign and magnitude of the effect depend on whether the conflict concentrates on relatively rich or poor regions within a country. As consequence, a problem of reverse causation might occur, imposing an endogeneity bias on the coefficient estimates. To deal with this possibility I have repeated the estimations using a one-period (5-year average) lagged value of the measure of regional inequality as an explanatory variable. The results are reported in Table A.3 in the appendix and confirm the findings discussed above.

\subsection{Country fixed effects estimates with ICRG conflict index}

The results presented in the previous section may be biased by omitted variables. There are numerous country-specific factors that might affect internal conflicts, which are unobservable or difficult to measure. For example, former colonial countries might have a higher risk of internal conflict, since the regions are often very heterogeneous in several respects (ethnicity, geography, size, etc.). These heterogeneities are related to the sometimes arbitrary demarcation of countries during the colonial era. Also, an unequal distribution of resources (water, oil, minerals, etc.) among the different regions of a country may affect conflict.

Therefore, it is important to check the robustness of results using country fixed effects. The country dummies capture the unobserved heterogeneity in the data. I utilize the ICRG index "risk of internal conflict" as the dependent variable, since 
Table 6: Panel fixed effects estimations using the ICRG conflict index

\begin{tabular}{|c|c|c|c|c|c|}
\hline & \multicolumn{5}{|c|}{ Dependent variable: risk of internal conflict (ICRG) } \\
\hline & $(1)$ & $(2)$ & $(3)$ & $(4)$ & $(5)$ \\
\hline \multirow{2}{*}{$G / N$} & 52.81 & 41.34 & 47.16 & 61.15 & 57.66 \\
\hline & $(1.57)$ & $(1.14)$ & $(1.12)$ & $(1.47)$ & $(1.35)$ \\
\hline \multirow[t]{2}{*}{$R E G I N E Q$} & 2.69 & $4.51^{* *}$ & $4.92^{* *}$ & $4.87^{* *}$ & $4.84^{* *}$ \\
\hline & $(1.46)$ & $(2.58)$ & $(2.16)$ & $(2.31)$ & $(2.29)$ \\
\hline \multirow[t]{2}{*}{$P O P$} & -2.89 & -3.17 & -2.75 & -2.65 & -3.20 \\
\hline & $(-1.19)$ & $(-1.36)$ & $(-1.04)$ & $(-1.02)$ & $(-1.08)$ \\
\hline \multirow[t]{2}{*}{$G D P P C$} & & & -0.26 & -0.424 & -0.36 \\
\hline & & & $(-0.40)$ & $(-0.70)$ & $(-0.59)$ \\
\hline \multirow[t]{2}{*}{$O I L / D I A M$} & & & & $0.76^{*}$ & $0.77^{*}$ \\
\hline & & & & $(2.00)$ & (1.99) \\
\hline \multirow[t]{2}{*}{$D E M O C$} & & & & & 0.57 \\
\hline & & & & & $(1.25)$ \\
\hline \multirow[t]{2}{*}{$L A G$} & & 0.13 & 0.12 & 0.13 & 0.11 \\
\hline & & $(1.66)$ & $(1.41)$ & $(1.43)$ & $(1.29)$ \\
\hline \multirow[t]{2}{*}{$C O N S T$} & 49.65 & 54.02 & 49.00 & 48.42 & 56.79 \\
\hline & (1.19) & $(1.34)$ & (1.13) & (1.14) & $(1.18)$ \\
\hline Fixed effects & yes & yes & yes & yes & yes \\
\hline Within $R^{2}$ & 0.11 & 0.16 & 0.16 & 0.18 & 0.18 \\
\hline Observations & 192 & 168 & 168 & 168 & 168 \\
\hline$N$ & 50 & 50 & 50 & 50 & 50 \\
\hline
\end{tabular}

it has more variation over time than the civil war data. The results of OLS regressions using similar control variables to those in the previous section are presented in Table A.3. Note that time-invariant control variables are dropped from the regression, due to their perfect collinearity with the country fixed effects.

Importantly, the measure of regional inequality has a positive and significant effect on the risk of internal conflict. It has even more explanatory power than the lagged value of the conflict measure. In this fixed effects model, also the resource variables have a positive effect, implying that the new discovery of resources increases the risk of internal conflict. This finding is in line with Collier and Hoeffler (2004).

\subsection{Estimates with PRIO25 and regional inequality measures based on Gennaioli et al. (2012)}

In this subsection, I estimate the empirical model using the inequality measures calculated based on Gennaioli et al. (2012). This increases the number of countries 
significantly over the baseline model, at the cost of the total loss of time variation in the data. The dependent variable is the incidence of armed conflict (PRIO25); therefore I present logit estimates.

In addition to the standard control variables, I also consider regional dummies for the Middle East and North Africa (MENA) and for South Asia $(S A)$. My estimations show that the baseline model is not able to predict the incidence of internal conflict very well for these two groups of countries, perhaps because ethnic conflicts are less important here. While regional dummies for sub-Saharan Africa and the other regions of the world have no significant effects, the dummies $M E N A$ and $S A$ have very strong effects. One reason for this is that the $M E N A$ countries have faced different internal and external conflicts due to incompatible territorial claims during the observation period, which have led to shifts of borders. Examples are the conflicts between Israel, Syria, Egypt, and Palestine over the Golan Heights, the Sinai Peninsula, and the West Bank and Gaza. At least in the case of Israel vs. Palestine, it is difficult to classify the conflict as internal or external. This brings up another problem, which is that there are missing values among the regional economic accounts for regions under conflict. The PRIO data classifies the conflict between Israel and Palestine as internal armed conflict. But regional data is not available for the West Bank and Gaza; therefore, the measure of regional inequality for Israel is biased downwards. Similar - although not that obvious - problems occur in 12 of the 98 countries in the sample. I have addressed this problem by adding a dummy variable (MISSING) for those countries where data on one or more subnational regions of a country is missing. Finally, I control for the degree of territorial fragmentation $(F R A G)$ of a country, measured by the average size of subnational regions. The regional data provided by Gennaioli et al. (2012) covers many lowand middle-income countries, where the territorial classifications are not comparable with those of OECD countries. This heterogeneity can affect the measure of regional inequality. The results are reported in Table 7 .

The coefficient of the measure of regional inequality is positive and significant in most of the specifications. Again, this is so whether the geographic controls are considered or not (column 4 and column 5). The sign and significance of the standard control variables are in line with Esteban et al. (2012a). In this broader data set, all three ethnic variables show the expected signs and - with the exception of the GreenbergGini index - are statistically significant. Concerning the additional control variables, the degree of territorial fragmentation has a negative sign, i.e., the larger the average size of subnational units, the lower is the risk of internal conflict. The coefficient of the dummy variable for countries where regional income data is missing is positive. This is quite suggestive, since the countries with regions under conflict are not able 
Table 7: Baseline specification with PRIO25, Fearon groupings, inequality measure based on Gennaioli at al. (2012)

\begin{tabular}{|c|c|c|c|c|c|c|c|}
\hline & \multicolumn{7}{|c|}{ Dependent variable: incidence of civil war (PRIO25) } \\
\hline & (1) & $(2)$ & (3) & (4) & (5) & $(6)$ & (7) \\
\hline \multirow[t]{2}{*}{$P$} & 4.17 & $4.59^{*}$ & $4.81^{* *}$ & $4.81^{* *}$ & $6.77^{* * *}$ & $6.42^{* * *}$ & $6.86^{* * *}$ \\
\hline & $(1.19)$ & $(1.92)$ & $(2.06)$ & $(2.05)$ & $(2.96)$ & $(2.78)$ & $(2.74)$ \\
\hline \multirow[t]{2}{*}{$F$} & $2.31^{* * *}$ & $1.65^{* * *}$ & $1.34^{* *}$ & $1.33^{*}$ & $1.69^{* *}$ & $1.62^{* *}$ & 0.89 \\
\hline & $(3.19)$ & $(2.75)$ & $(1.97)$ & $(1.87)$ & $(2.42)$ & $(2.39)$ & $(1.39)$ \\
\hline \multirow{2}{*}{$G / N$} & -4.27 & -3.43 & -2.62 & -2.63 & -5.42 & -4.51 & -5.01 \\
\hline & $(-0.94)$ & $(-0.91)$ & $(-0.66)$ & $(-0.66)$ & $(-1.22)$ & $(-1.10)$ & $(-0.84)$ \\
\hline \multirow[t]{2}{*}{$R E G I N E Q$} & $1.57^{* *}$ & $1.13^{* *}$ & 0.98 & 0.98 & $1.28^{* *}$ & $1.30^{* *}$ & $2.05^{* * *}$ \\
\hline & $(2.02)$ & $(1.97)$ & $(1.62)$ & $(1.60)$ & $(1.97)$ & $(1.99)$ & $(3.07)$ \\
\hline \multirow{2}{*}{$F R A G$} & $-0.01^{* *}$ & $-0.01 *$ & $-0.01 *$ & $-0.01 *$ & -0.01 & -0.01 & -0.01 \\
\hline & $(-2.00)$ & $(-1.91)$ & $(-1.91)$ & $(-1.89)$ & $(-1.51)$ & $(-1.55)$ & $(-1.31)$ \\
\hline \multirow[t]{2}{*}{$M I S S I N G$} & 1.03 & 0.88 & $0.92^{*}$ & $0.92^{*}$ & $0.93^{*}$ & $0.86^{*}$ & 0.69 \\
\hline & $(1.47)$ & (1.64) & $(1.76)$ & $(1.75)$ & $(1.84)$ & $(1.76)$ & $(1.42)$ \\
\hline \multirow[t]{2}{*}{$M E N A$} & $1.20^{* * *}$ & $0.98^{* * *}$ & $1.06^{* * *}$ & $1.05^{* * *}$ & $1.44^{* * *}$ & $1.59 * * *$ & $2.14^{* * *}$ \\
\hline & $(2.66)$ & $(3.18)$ & $(3.45)$ & $(3.35)$ & $(4.22)$ & $(4.05)$ & $(4.18)$ \\
\hline \multirow[t]{2}{*}{$S A$} & $1.46^{* * *}$ & $1.30^{* * *}$ & $1.09^{* * *}$ & $1.10^{* * *}$ & $1.26^{* * *}$ & $1.19^{* * *}$ & $1.80^{* * *}$ \\
\hline & $(4.98)$ & $(3.99)$ & $(2.74)$ & $(2.71)$ & $(2.99)$ & $(2.85)$ & $(3.42)$ \\
\hline \multirow{2}{*}{$P O P$} & $0.47^{* * *}$ & $0.34^{* * *}$ & $0.38^{* * *}$ & $0.38^{* * *}$ & 0.16 & 0.16 & 0.19 \\
\hline & $(2.81)$ & $(2.72)$ & $(2.82)$ & $(2.83)$ & $(1.22)$ & $(1.24)$ & $(1.32)$ \\
\hline \multirow[t]{2}{*}{$G D P P C$} & & & -0.19 & -0.19 & $-0.31^{* *}$ & $-0.40^{* *}$ & $-0.45^{*}$ \\
\hline & & & $(-1.17)$ & $(-1.19)$ & $(-2.08)$ & $(-2.52)$ & $(-1.83)$ \\
\hline \multirow[t]{2}{*}{$O I L / D I A M$} & & & & 0.02 & -0.11 & -0.08 & -0.10 \\
\hline & & & & $(0.07)$ & $(-0.38)$ & $(-0.26)$ & $(-0.34)$ \\
\hline \multirow[t]{2}{*}{$M O U N T$} & & & & & 0.01 & 0.01 & 0.01 \\
\hline & & & & & $(0.16)$ & $(0.30)$ & $(0.63)$ \\
\hline \multirow{2}{*}{$N C O N T$} & & & & & $1.31^{* * *}$ & $1.30^{* * *}$ & $1.51^{* * *}$ \\
\hline & & & & & $(3.09)$ & $(3.07)$ & $(3.17)$ \\
\hline \multirow[t]{2}{*}{$D E M O C$} & & & & & & 0.33 & 0.23 \\
\hline & & & & & & $(0.95)$ & $(0.56)$ \\
\hline \multirow[t]{2}{*}{ EXCONS } & & & & & & & -0.13 \\
\hline & & & & & & & $(-0.28)$ \\
\hline \multirow[t]{2}{*}{$A Z T O C R$} & & & & & & & $-1.04^{* *}$ \\
\hline & & & & & & & $(-2.35)$ \\
\hline POLRIGHTS & & & & & & & $\begin{array}{c}0.83^{*} \\
(1.89)\end{array}$ \\
\hline \multirow[t]{2}{*}{$C I V L I B$} & & & & & & & -0.30 \\
\hline & & & & & & & $(-0.63)$ \\
\hline \multirow[t]{2}{*}{$L A G$} & & $2.52^{* * *}$ & $2.51^{* * *}$ & $2.51^{* * *}$ & $2.40^{* * *}$ & $2.39^{* * *}$ & $2.47^{* * *}$ \\
\hline & & $(10.05)$ & $(10.02)$ & $(9.99)$ & $(9.57)$ & $(9.50)$ & $(9.47)$ \\
\hline \multirow[t]{2}{*}{ CONST } & $-10.60^{* * *}$ & $-9.07^{* * *}$ & $-8.05^{* * *}$ & $-8.01 * * *$ & $-4.07^{*}$ & -3.63 & -3.65 \\
\hline & $(-3.91)$ & $(-4.45)$ & $(-3.50)$ & $(-3.52)$ & $(-1.79)$ & $(-1.59)$ & $(-1.27)$ \\
\hline Pseudo- $R^{2}$ & 0.19 & 0.37 & 0.37 & 0.37 & 0.39 & 0.39 & 0.41 \\
\hline Observations & 865 & 770 & 770 & 770 & 770 & 770 & 691 \\
\hline$N$ & 98 & 98 & 98 & 98 & 98 & 98 & 97 \\
\hline
\end{tabular}

Notes: $z$-values are reported in parentheses. Robust standard errors adjusted for clustering have been employed to compute $z$-statistics. ${ }^{* * *}, * *$, and $*$ indicate significance at $1 \%, 5 \%$, and $10 \%$, respectively. 
to report regional economic accounts for the conflict region. The $M E N A$ and $S A$ suggest that the incidence of internal conflict is higher in these regions, which cannot be explained by the other control variables.

It is important to mention that the inclusion of the MENA dummy is crucial to get a significant effect for the measure of regional inequality in this country sample. Without the regional fixed effect, I do not get significant results in this country sample. The main finding is also obtained and significant if I exclude $M E N A$ countries from the data set. If that is done, the effect of regional inequalities on conflict is positive and significant without considering the additional controls. In general, the controls considered in addition to those used by Esteban et al. (2012a) are not decisive. I always get significant effects at least in the specification which considers all standard control variables (column 7).

\subsection{Different conflict variables}

Up to this point, my analysis has used the binary conflict variable PRIO25 and the ICRG index "risk of internal conflict". PRIO reports other indicators, including nonbinary alternatives, which I use for robustness tests in this section. Therein I follow closely Esteban et al. (2012a). The results reported in Table 8 reproduce Table 3 of Esteban et al. (2012, p. 1323), but the equation is augmented with the measure of regional inequality (based on Gennaioli et al. (2012)) and the full set of standard and additional control variables. Column 1 reproduces the results reported in column 7 from the baseline specification for reasons of better comparability. Column 2 focuses on intermediate conflicts (PRIOCW). Column 3 considers civil wars (PRIO1000). Column 4 reports results of a nonbinary measure of conflict intensity (PRIOINT). The variable has the value 0 for episodes of "peace", the value 1 for events that satisfy PRIO25 but not PRIO1000, and the value 2 for PRIO1000 events. Column 5 considers an alternative continuous measure of conflict intensity. For this, I use the index of social conflict $(I S C)$ provided by the Cross-National Time-Series Data Archive (CNTS). Column 6 reports results using the ICRG index "risk of internal conflict", which has not yet been combined with the broader data set of regional inequalities.

The effect of the measure of regional inequality is positive and significant for all specifications that use categorial PRIO data as well as in the specification that uses the measure ISC of conflict intensity (columns 2-5). In the regression that uses the ICRG index "risk of internal conflict" as dependent variable, the coefficient of the measure of regional inequality is positive as expected, but the effect is not significant at conventional confidence levels. However, the $t$-value is quite high 
Table 8: Different conflict variables, Fearon groupings, inequality measure based on Gennaioli at al. (2012)

\begin{tabular}{|c|c|c|c|c|c|c|}
\hline & \multicolumn{6}{|c|}{ Dependent variable: } \\
\hline & $\begin{array}{l}\text { PRIO25 } \\
\text { (1) }\end{array}$ & $\begin{array}{l}\text { PRIOCW } \\
\quad(2)\end{array}$ & $\begin{array}{c}\text { PRIO1000 } \\
\text { (3) }\end{array}$ & $\begin{array}{c}\text { PRIOINT } \\
(4)\end{array}$ & $\begin{array}{c}I S C \\
(5)\end{array}$ & $\begin{array}{l}I C R G \\
\quad(6)\end{array}$ \\
\hline \multirow[t]{2}{*}{$P$} & $6.86^{* * *}$ & 3.66 & 2.39 & $5.38^{* *}$ & $25.30 * *$ & 1.19 \\
\hline & $(2.74)$ & $(1.23)$ & $(0.80)$ & $(2.35)$ & $(2.16)$ & $(0.95)$ \\
\hline \multirow[t]{2}{*}{$F$} & 0.89 & 0.94 & 0.93 & 0.97 & 1.01 & 0.40 \\
\hline & $(1.39)$ & $(1.14)$ & $(0.89)$ & $(1.60)$ & $(0.35)$ & $(1.49)$ \\
\hline \multirow[t]{2}{*}{$G / N$} & -5.01 & -7.04 & -3.87 & -6.15 & -3.79 & $-2.59 * *$ \\
\hline & $(-0.84)$ & $(-0.91)$ & $(-0.60)$ & $(-1.16)$ & $(-0.47)$ & $(-2.25)$ \\
\hline \multirow[t]{2}{*}{$R E G I N E Q$} & $2.05^{* * *}$ & $2.29 * * *$ & $2.78^{* * *}$ & $1.87 * * *$ & $4.62^{*}$ & 0.50 \\
\hline & $(3.07)$ & $(2.99)$ & $(2.84)$ & $(3.11)$ & $(1.78)$ & $(1.60)$ \\
\hline \multirow[t]{2}{*}{$A R E A / U N I T S$} & -0.01 & -0.01 & -0.01 & -0.01 & -0.01 & -0.01 \\
\hline & $(-1.31)$ & $(-1.17)$ & $(-0.70)$ & $(-1.12)$ & $(-1.64)$ & $(-0.75)$ \\
\hline \multirow[t]{2}{*}{$M I S S I N G$} & 0.69 & 0.85 & 0.32 & 0.36 & 3.70 & 0.22 \\
\hline & $(1.42)$ & $(1.40)$ & $(0.49)$ & $(0.84)$ & $(1.28)$ & $(0.83)$ \\
\hline \multirow[t]{2}{*}{$M E N A$} & $2.14^{* * *}$ & $1.92^{* * *}$ & $1.39 * *$ & $1.66^{* * *}$ & $6.07 * * *$ & -0.01 \\
\hline & $(4.18)$ & $(3.18)$ & $(2.47)$ & $(4.12)$ & $(3.22)$ & $(-0.05)$ \\
\hline \multirow[t]{2}{*}{$S A$} & $1.80^{* * *}$ & 1.20 & $1.76^{* *}$ & $1.51^{* *}$ & $5.34^{*}$ & 0.86 \\
\hline & $(3.42)$ & $(1.42)$ & $(2.47)$ & $(2.57)$ & $(1.83)$ & (1.63) \\
\hline \multirow[t]{2}{*}{$P O P$} & 0.19 & 0.18 & 0.17 & 0.09 & $0.85^{* *}$ & -0.04 \\
\hline & $(1.32)$ & $(0.89)$ & $(0.90)$ & $(0.68)$ & $(2.04)$ & $(-1.01)$ \\
\hline \multirow[t]{2}{*}{$G D P P C$} & $-0.45^{*}$ & -0.24 & -0.36 & -0.30 & $-2.76^{* * *}$ & $-0.26^{* *}$ \\
\hline & $(-1.83)$ & $(-0.73)$ & $(-1.19)$ & $(-1.41)$ & $(-2.94)$ & $(-2.45)$ \\
\hline \multirow{2}{*}{$O I L / D I A M$} & -0.10 & 0.22 & -0.33 & -0.22 & -0.03 & 0.10 \\
\hline & $(-0.34)$ & $(0.54)$ & $(-0.76)$ & $(-0.85)$ & $(-0.02)$ & $(0.79)$ \\
\hline \multirow[t]{2}{*}{$M O U N T$} & 0.01 & 0.01 & 0.01 & 0.01 & 0.03 & 0.01 \\
\hline & $(0.63)$ & $(1.00)$ & $(0.56)$ & $(0.37)$ & (1.04) & $(0.05)$ \\
\hline \multirow[t]{2}{*}{ NCONT } & $1.51^{* * *}$ & $1.32^{* *}$ & $1.06^{*}$ & $1.09 * * *$ & $4.87 * * *$ & $0.41^{* *}$ \\
\hline & $(3.17)$ & $(2.37)$ & $(1.83)$ & $(2.63)$ & $(2.73)$ & $(2.34)$ \\
\hline \multirow[t]{2}{*}{$D E M O C$} & 0.23 & 0.21 & -0.60 & 0.01 & -2.21 & $-0.62 * *$ \\
\hline & $(0.56)$ & $(0.43)$ & $(-1.01)$ & $(0.03)$ & $(-1.37)$ & $(-2.18)$ \\
\hline \multirow[t]{2}{*}{ EXCONS } & -0.13 & 0.22 & -0.83 & -0.22 & $-2.84^{*}$ & -0.22 \\
\hline & $(-0.28)$ & $(0.40)$ & $(-1.43)$ & $(-0.53)$ & $(-1.86)$ & $(-1.25)$ \\
\hline \multirow[t]{2}{*}{$A U T O C R$} & $-1.04^{* *}$ & $-1.22^{* *}$ & $-1.40^{* *}$ & $-1.03^{* *}$ & $-2.25^{*}$ & -0.25 \\
\hline & $(-2.35)$ & $(-2.18)$ & $(-2.18)$ & $(-2.44)$ & $(-1.81)$ & $(-1.30)$ \\
\hline \multirow[t]{2}{*}{ POLRIGHTS } & $0.83^{*}$ & 0.40 & 0.53 & 0.43 & -0.54 & -0.05 \\
\hline & $(1.89)$ & $(0.63)$ & $(0.75)$ & (1.09) & $(-0.28)$ & $(-0.17)$ \\
\hline \multirow[t]{2}{*}{$C I V L I B$} & -0.30 & 0.17 & 0.23 & 0.09 & -2.88 & -0.13 \\
\hline & $(-0.63)$ & $(0.28)$ & $(0.36)$ & $(0.21)$ & $(-1.59)$ & $(-0.53)$ \\
\hline \multirow[t]{2}{*}{$L A G$} & $2.47^{* * *}$ & $3.37 * * *$ & $2.53^{* * *}$ & $1.86^{* * *}$ & $0.40^{* * *}$ & $0.62^{* * *}$ \\
\hline & $(9.47)$ & $(10.31)$ & $(6.66)$ & $(8.59)$ & $(7.78)$ & $(19.36)$ \\
\hline \multirow[t]{2}{*}{ CONST } & -3.65 & -6.09 & -4.35 & & 13.61 & $3.94^{* * *}$ \\
\hline & $(-1.27)$ & $(-1.78)$ & $(-1.43)$ & & $(1.37)$ & $(3.28)$ \\
\hline Pseudo- $R^{2}$ & 0.41 & 0.5 & 0.37 & 0.34 & 0.42 & 0.72 \\
\hline Observations & 691 & 691 & 691 & 691 & 691 & 406 \\
\hline$C$ & 97 & 97 & 97 & 97 & 97 & 90 \\
\hline
\end{tabular}

Notes: Columns 1-3, logit; column 4, ordered logit; columns 5-6, ordinary least squares (OLS); $z$ values or $t$-values are reported in parentheses. Robust standard errors adjusted for clustering have been employed. $* * *, * *$, and $*$ indicate significance at $1 \%, 5 \%$, and $10 \%$, respectively. 
(1.60). I conclude from this exercise that the effect of regional inequality on internal conflicts is robust to these measurement issues.

\section{$5 \quad$ Summary and Conclusions}

This paper studies the influence of interregional income inequalities within countries on internal conflict. I argue, based on the existing theoretical literature, that regional inequalities increase the risk of internal conflict. Regional inequalities are a particular type of horizontal inequalities, which are expected to be a major determinant of conflict [see Stewart (2000)]. This hypothesis is tested empirically using cross-country and panel data. Regional inequalities are measured by the populationweighted coefficient of variation of regional GDP per capita within countries, which is commonly used in economic geography [see, e.g., Williamson (1965)]. Two data sources are used: Lessmann (2011), who provides unique panel data on 56 countries (835 subnational regions) covering the period 1980-2009, and Gennaioli et al. (2012), who provide cross-section data on 110 countries (1569 subnational regions) for the year 2005. Conflict is measured by the incidence of civil war as reported by the Uppsala Conflict Data Program and the Peace Research Institute Oslo, and the measure "risk of internal conflict" reported by the PRS Group's International Country Risk Guide. The econometric analysis shows that interregional inequalities within countries increase the risk of internal conflict. This finding is robust to the inclusion of country fixed effects, regional fixed effects, and alternative conflict measures.

The policy implications of this work are straightforward. Policies that reduce regional inequalities might also contribute to a reduction in the risk of internal conflicts. This might save life and stimulate economic growth. The difficult question is, however, which policies are appropriate. One instrument might be the decentralization of the public sector. A number of studies, such as Lessmann (2009), Rodríguez-Pose and Ezcurra (2010), and Lessmann (2012), find decentralization to reduce regional inequalities overall, but the effects are not significant in developing countries. Therefore, this policy instrument is only suitable for high-income countries. Another instrument might be fiscal transfers which aim at an equalization of living standards; they are common in many federations such as Germany or Canada. However, the empirical evidence on the effectiveness of such transfers in reducing regional inequalities points at precisely the reverse relationship [see Kessler et al. (2011)]. The reason is that interregional transfers undermine the household's incentive to migrate from poor to rich regions, thus inhibiting the natural convergence process. 
In light of this, it seems more appropriate to foster policies that aim to increase the mobility of people. This may include infrastructure investments or education policies, since highly educated people have a higher probability to migrate. Moreover, a recent study by Gennaioli et al. (2012) shows that differences in human capital are the major cause of differences in regional growth. Therefore policies which aim at a better education in poor regions of a country might also reduce the risk of conflict. 


\section{References}

Alesina, A. and E. Spolaore (1997). On the Number and Size of Nations. The Quarterly Journal of Economics, 112(4), pp. 1027-1056.

Barro, R. J. and X. Sala-i-Martin (1992). Convergence. Journal of Political Economy, 100(2), pp. 223-251.

Bolton, P. and G. Roland (1997). The Break-Up of Nations: A Political Economy Analysis. Quarterly Journal of Economics, 112(4), pp. 1057-1090.

Buhaug, H., K. Gleditschm, H. Holtermann, G. Østby, , and A. F. Tollefsen (2012). It's the local economy, stupid! Geographic wealth dispersion and conflict outbreak location. Journal of Conflict Resolution, 55(5), pp. 814-840.

Collier, P. and A. Hoeffler (2004). Greed and grievance in civil war. Oxford Economic Papers, 56(4), pp. 563-595.

Cramer, C. (2003). Does inequality cause conflict? Journal of International Development, 15(4), pp. 397-412.

Cramer, C. (2005). Inequality and Conflict: A Review of an Age-Old Concern. Identities, Conflict and Cohesion Programme Paper 11, United Nations Research Institute for Social Development.

Dalton, H. (1920). The Measurement of the Inequality of Incomes. Economic Journal, 30(119), pp. 348-361.

Deininger, K. and L. Squire (1996). A New Data Set Measuring Income Inequality. The World Bank Economic Review, 10(3), pp. 565-591.

Deiwiks, C., L. Cederman, and K. Gleditsch (2012). Inequality and conflict in federations. Journal of Peace Research, 49(2), pp. 289-304.

Doyle, M. W. and N. Sambanis (2000). International Peacebuilding: A Theoretical and Quantitative Analysis. American Political Science Review, 94(4), pp. 779-801.

Esteban, J., L. Mayoral, and D. Ray (2012a). Ethnicity and Conflict: An Empirical Study. American Economic Review, 102(4), pp. 1310-42.

Esteban, J., L. Mayoral, and D. Ray (2012b). Ethnicity and Conflict: Theory and Facts. Science, 336(6083), pp. 858-865.

Esteban, J. and D. Ray (1994). On the Measurement of Polarization. Econometrica, 62(4), pp. 819-51. 
Esteban, J. and D. Ray (2011a). Linking Conflict to Inequality and Polarization. American Economic Review, 101(4), pp. 1345-74.

Esteban, J. and D. Ray (2011b). A Model Of Ethnic Conflict. Journal of the European Economic Association, 9(3), pp. 496-521.

Fearon, J. D. (2005). Primary Commodity Exports and Civil War. Journal of Conflict Resolution, 49(4), pp. 483-507.

Fearon, J. D. and D. D. Laitin (2003). Ethnicity, Insurgency, and Civil War. American Political Science Review, 97(1), pp. 75-90.

Gennaioli, N., R. L. Porta, F. L. de Silanes, and A. Shleifer (2012). Human Capital and Regional Development. Quartely Journal of Economics, forthcoming.

Gleditsch, N. P., P. Wallensteen, M. Eriksson, M. Sollenberg, and H. Strand (2002). Armed Conflict 1946-2001: A New Dataset. Journal of Peace Research, 39(5), pp. 615-637.

Gourevitch, P. (1979). The reemergence of "peripheral nationalisms": some comparative speculations on the spatial distribution of political leadership and economic growth. Comparative Studies in Society and History, 21(3), pp. 303-322.

Hale, T. (2003). The Theoretical Basics of Popular Inequality Measures; Online Computation of Examples. University of Texas Inequality Project.

Harbom, L. and P. Wallensteen (2010). Armed Conflict, 1946-2009. Journal of Peace Research, 47(4), pp. 501-509.

Hechter, M. (1975). Internal Colonialism: The Celtic Fringe in British National Development. Berkeley: University of California Press.

Kanbur, R. (2005). Spatial Inequality and Development; Overview of UNU-WIDER Project. Working Papers id:215, eSocialSciences.

Kanbur, R. and A. Venables (2005). Spatial Inequality and Development. In R. Kanbur and A. Venables (editors), Spatial Inequality and Development, pp. 3-11. New York: Oxford University Press.

Kessler, A. S., N. A. Hansen, and C. Lessmann (2011). Interregioinal Redistribution and Mobility in Federations: A Positive Approach. Review of Economic Studies, 78(4), pp. 1345-1378.

Kézdi, G. (2004). Robust Standard Error Estimation in Fixed-Effects Panel Models. Hungarian Statistical Review Special, 9, pp. 96-116. 
Lessmann, C. (2009). Fiscal Decentralization and Regional Disparity: Evidence from Cross-section and Panel Data. Environment and Planning A, 41(10), pp. $2455-2473$.

Lessmann, C. (2011). Spatial Inequality and Development - Is there an Inverted-U Relationship? CESifo Working Paper Series 3622, CESifo Group Munich.

Lessmann, C. (2012). Regional inequality and decentralization: an empirical analysis. Environment and Planning A, 44(6), pp. 1363-1388.

Lessmann, C. (2013). Foreign Direct Investment and Regional Inequality: A Panel Data Analysis. China Economic Review, 24, pp. 129-149.

Lichbach, M. I. (1989). An Evaluation of "Does Economic Inequality Breed Political Conflict?" Studies. World Politics, 41(4), pp. 431-470.

Mehran, F. (1976). Linear Measures of Income Inequality. Econometrica, 44(4), pp. 805-809.

Nordhaus, W., Q. Azam, D. Corderi, K. Hood, N. M. Victor, M. Mohammed, A. Miltner, and J. Weiss (2006). The G-Econ Database on Gridded Output: Methods and Data. Discussion paper, Yale University.

Nordhaus, W. D. (2006). Geography and macroeconomics: New data and new findings. Proceedings of the National Academy of Scienes of the UNited States of America, 103(10), pp. 3510-3517.

Oates, W. E. (1972). Fiscal Federalism. New York: Harcourt Brace Jovanovich.

Pigou, A. C. (1912). Wealth and Welfare. London: Macmillan.

Ray, D. (1998). Development economics. Princeton: Princeton University Press.

Rodríguez-Pose, A. (2012). Trade and Regional Inequality. Economic Geography, 88(2), pp. 109-136.

Rodríguez-Pose, A. and R. Ezcurra (2010). Does Decentralization Matter for Regional Disparities? A Cross-Country Analysis. Journal of Economic Geography, 10(5), pp. 619-644.

Rogers, W. H. (1993). Regression standard errors in clustered samples. Stata Technical Bulletin, 13, pp. 19-23.

Sala-i-Martin, X. (1996). Regional Cohesion: Evidence and Theories of Regional Growth and Convergence. European Economic Review, 40(6), pp. 1325-1352. 
Sen, A. (1973). On Economic Inequality. New York: Norton.

Sen, A. (1997). On Economic Inequality. Oxford: Oxford University Press.

Østby, G. (2008). Polarization, Horizontal Inequalities and Violent Civil Conflict. Journal of Peace Research, 45(2), pp. 143-162.

Østby, G., R. Nordås, and J. K. Rød (2009). Regional Inequalities and Civil Conflict in Sub-Saharan Africa. International Studies Quarterly, 53(2), pp. 301-324.

Stewart, F. (2000). Crisis prevention: tackling horizontal inequalities. Oxford Development Studies, 28(3), pp. 245-262.

Stewart, F. (2002). Horizontal Inequalities: A Neglected Dimension of Development. QEH Working Paper Series 81, University of Oxford.

Williamson, J. G. (1965). Regional Inequality and the Process of National Development: A Description of Patterns. Economic Development and Cultural Change, 13(4), pp. 3-45. 
Table A.1: Data sources \& definitions

\begin{tabular}{|c|c|c|}
\hline Variable & Definition & Source \\
\hline \multicolumn{3}{|l|}{ Conflict variables } \\
\hline PRIO25 & $\begin{array}{l}\text { "armed conflict" with at least } 25 \text { battle-related death per year } \\
\text { and per incompatibility }\end{array}$ & Esteban et al. (2012a) \\
\hline PRIOCW & $\begin{array}{l}\text { "intermediate armed conflicts", which includes armed conflicts } \\
\text { with a minimum of } 1,000 \text { deaths over the course of the conflict }\end{array}$ & Esteban et al. (2012a) \\
\hline PRIO1000 & $\begin{array}{l}\text { "war" with a threshold of battle-related deaths of at least } \\
1,000 \text { per year and per incompatibility }\end{array}$ & Esteban et al. (2012a) \\
\hline PRIOINT & $\begin{array}{l}\text { "conflict intensity" from PRIO: The variable has the value of } \\
0 \text { for episodes of "peace", the value } 1 \text { for events that sat- } \\
\text { isfy PRIO25 that are not PRIO1000, and the value } 2 \text { for } \\
\text { PRIO1000 events }\end{array}$ & Esteban et al. (2012a) \\
\hline$I S C$ & $\begin{array}{l}\text { Index of social conflict. The Cross-National Time-Series Data } \\
\text { Archive (CNTS) computes the index as the weighted aver- } \\
\text { age of eight variables related to social unrest: assassinations, } \\
\text { general strikes, guerrilla warfare, major government crises, } \\
\text { purges, riots, revolutions, and anti-government demonstra- } \\
\text { tions }\end{array}$ & Esteban et al. (2012a) \\
\hline ICRG index & $\begin{array}{l}\text { "risk of internal conflict" as reported by the PRS Group's } \\
\text { International Country Risk Guide. The index is created from } \\
\text { an annual survey of experts who rate a country's risk of conflict } \\
\text { in three categories: civil war and coup threat, terrorism and } \\
\text { political violence, and civil disorder. }\end{array}$ & PRS Group \\
\hline \multicolumn{3}{|l|}{ Regional inequality } \\
\hline REGINEQ & $\begin{array}{l}\text { Measure of interregional inequality within countries: the } \\
\text { population-weighted coefficient of variation of regional GDP } \\
\text { per capita }\end{array}$ & \begin{tabular}{|l|} 
Lessmann $(2011)$, Gen- \\
naioli et al. (2012)
\end{tabular} \\
\hline \multicolumn{3}{|l|}{ Control variables } \\
\hline GDPPC & $\begin{array}{l}\text { Log of real GDP per capita corresponding to the first year of } \\
\text { each five-year period }\end{array}$ & Esteban et al. (2012a) \\
\hline POP & Population in millions & Esteban et al. 2012a) \\
\hline OIL/DIA & $\begin{array}{l}\text { Dummy variable for countries which are "rich in diamonds" } \\
\text { and/or "rich in oil" }\end{array}$ & Esteban et al. $(\overline{2012 a})$ \\
\hline MOUNT & Percent mountainous terrain & Esteban et al. (2012a) \\
\hline NCONT & $\begin{array}{l}\text { Noncontinguous states, referring to countries with territory } \\
\text { holding at least } 10,000 \text { people and seperated from the land } \\
\text { area containing the capital city either by water or by foreign } \\
\text { land }\end{array}$ & Esteban et al. $(\overline{2012 \mathrm{a}})$ \\
\hline DEMOC & $\begin{array}{l}\text { Democracy as reported by the Polity IV data set. Dummy for } \\
\text { Polity2 index greater than } 3\end{array}$ & Esteban et al. (2012a) \\
\hline $\mathrm{P}$ & $\begin{array}{l}\text { Polarization. Measures the differences between languages; see } \\
\text { Esteban et al. (2012a) for details }\end{array}$ & Esteban et al. (2012a) \\
\hline $\mathrm{F}$ & $\begin{array}{l}\text { Fractionalization. Calculated from group shares of different } \\
\text { ethnic groups, see Esteban et al. (2012a) for details }\end{array}$ & Esteban et al. (2012a) \\
\hline $\mathrm{G} / \mathrm{N}$ & Greenberg-Gini index; see Esteban et al. (2012a) for details & Esteban et al. 2012a \\
\hline EXCONS & $\begin{array}{l}\text { (Lack of) executive constraints (Polity IV data). Dummy with } \\
\text { value } 1 \text { if constraints are smaller than } 0.4\end{array}$ & Esteban et al. (2012a) \\
\hline AUTOCR & $\begin{array}{l}\text { Autocracy as reported by the Polity IV data set. For data } \\
\text { transformation see Esteban et al. (2012a) }\end{array}$ & Esteban et al. (2012a) \\
\hline POLRIGHTS & $\begin{array}{l}\text { (Lack of) political rights as reported by Freedom House. For } \\
\text { data transformation see Esteban et al. (2012a) }\end{array}$ & Esteban et al. (2012a) \\
\hline CIVLIB & $\begin{array}{l}\text { (Lack of) civil liberties as reported by Freedom House. For } \\
\text { data transformation see Esteban et al. (2012a) }\end{array}$ & Esteban et al. (2012a) \\
\hline AREA/UNITS & $\begin{array}{l}\text { Country size in square kilometers divided by the number of } \\
\text { subnational regions }\end{array}$ & $\begin{array}{l}\text { Lessmann }(2011), \text { Gen- } \\
\text { naioli et al. }(2012) \\
\end{array}$ \\
\hline
\end{tabular}


Table A.2: Summary statistics of all variables

\begin{tabular}{|c|c|c|c|c|c|}
\hline Variable & Obs. & Mean & Std. Dev. & Min & $\operatorname{Max}$ \\
\hline \multicolumn{6}{|l|}{ Conflict variables } \\
\hline PRIO25 & 865 & 0.24 & 0.43 & 0 & 1 \\
\hline PRIOCW & 865 & 0.16 & 0.36 & 0 & 1 \\
\hline PRIO1000 & 865 & 0.07 & 0.26 & 0 & 1 \\
\hline PRIOINT & 865 & 0.31 & 0.60 & 0 & 2 \\
\hline ISC & 860 & 10.89 & 16.14 & 0 & 127.75 \\
\hline ICRG index & 494 & 3.15 & 2.53 & 0 & 11.65 \\
\hline \multicolumn{6}{|l|}{ Regional inequality } \\
\hline REGINEQ (Lessmann, 2012) & 192 & 0.28 & 0.17 & 0.05 & 0.91 \\
\hline REGINEQ (Gennaioli et al. 2011) & 865 & 0.35 & 0.19 & 0.08 & 1.01 \\
\hline \multicolumn{6}{|l|}{ Control variables } \\
\hline GDPPC & 865 & 8.20 & 1.07 & 5.38 & 10.32 \\
\hline POP & 865 & 16.41 & 1.42 & 12.57 & 20.99 \\
\hline OIL/DIA & 865 & 0.29 & 0.46 & 0 & 1 \\
\hline MOUNT & 865 & 18.29 & 19.78 & 0 & 82.20 \\
\hline NCONT & 865 & 0.21 & 0.41 & 0 & 1 \\
\hline DEMOC & 864 & 0.56 & 0.50 & 0 & 1 \\
\hline $\mathrm{P}$ & 865 & 0.05 & 0.05 & 0 & 0.25 \\
\hline $\mathrm{F}$ & 865 & 0.39 & 0.25 & 0 & 0.84 \\
\hline $\mathrm{G} / \mathrm{N}$ & 865 & 0.02 & 0.06 & 0 & 1.13 \\
\hline EXCONS & 861 & 0.44 & 0.50 & 0 & 1 \\
\hline AUTOCR & 861 & 0.24 & 0.43 & 0 & 1 \\
\hline POLRIGHTS & 710 & 0.38 & 0.49 & 0 & 1 \\
\hline CIVLIB & 710 & 0.42 & 0.49 & 0 & 1 \\
\hline AREA/UNITS & 865 & 68.14 & 138.38 & 1.48 & 960.00 \\
\hline MISSING & 865 & 0.09 & 0.28 & 0 & 1 \\
\hline MENA & 865 & 0.08 & 0.27 & 0 & 1 \\
\hline $\mathrm{SA}$ & 865 & 0.05 & 0.21 & 0 & 1 \\
\hline
\end{tabular}


Table A.3: Logit estimates, lagged regional inequality

\begin{tabular}{|c|c|c|c|c|c|c|c|}
\hline & \multicolumn{7}{|c|}{ Dependent variable: incidence of civil war (PRIO25) } \\
\hline & (1) & (2) & $(3)$ & (4) & $(5)$ & (6) & (7) \\
\hline \multirow[t]{2}{*}{$\mathrm{P}$} & 6.99 & 11.92 & 12.99 & 13.48 & 4.99 & -0.07 & 116.40 \\
\hline & $(0.62)$ & $(1.15)$ & $(1.22)$ & $(1.21)$ & $(0.30)$ & $(-0.00)$ & $(1.40)$ \\
\hline \multirow[t]{2}{*}{$\mathrm{F}$} & $4.50^{* *}$ & $3.85^{* * *}$ & $3.73^{* *}$ & 3.08 & 4.74 & 7.02 & 2.47 \\
\hline & $(2.39)$ & $(2.58)$ & $(2.32)$ & $(1.44)$ & $(1.43)$ & $(1.32)$ & $(0.33)$ \\
\hline \multirow[t]{2}{*}{$\mathrm{G} / \mathrm{N}$} & -14.38 & 1.88 & -9.27 & -8.86 & 44.59 & 94.40 & 95.94 \\
\hline & $(-0.41)$ & $(0.10)$ & $(-0.41)$ & $(-0.38)$ & $(1.24)$ & $(0.98)$ & (1.08) \\
\hline \multirow[t]{2}{*}{ REGINEQ $_{t-1}$} & $2.82^{*}$ & -0.10 & -1.65 & -1.62 & $22.87^{*}$ & 35.06 & $59.85 * *$ \\
\hline & $(1.68)$ & $(-0.05)$ & $(-0.81)$ & $(-0.85)$ & $(1.73)$ & $(1.36)$ & $(2.18)$ \\
\hline \multirow[t]{2}{*}{ POP } & $0.75^{* * *}$ & $0.98^{* *}$ & $0.97^{* *}$ & $0.82^{*}$ & -0.31 & -0.65 & 3.42 \\
\hline & $(3.45)$ & $(2.33)$ & $(1.97)$ & $(1.65)$ & $(-0.48)$ & $(-0.71)$ & $(0.57)$ \\
\hline \multirow[t]{2}{*}{ GDPPC } & & & -0.54 & -0.54 & -1.30 & -1.03 & -5.93 \\
\hline & & & $(-1.15)$ & $(-1.11)$ & $(-0.96)$ & $(-0.64)$ & $(-0.51)$ \\
\hline \multirow[t]{2}{*}{ OIL/DIAM } & & & & 0.54 & 2.63 & 3.12 & 3.79 \\
\hline & & & & $(0.40)$ & $(1.58)$ & $(1.32)$ & (1.39) \\
\hline \multirow[t]{2}{*}{ MOUNT } & & & & & $0.20^{* *}$ & 0.29 & 0.23 \\
\hline & & & & & $(2.32)$ & $(1.62)$ & (1.11) \\
\hline \multirow[t]{2}{*}{ NCONT } & & & & & $13.07^{* *}$ & 19.40 & 34.16 \\
\hline & & & & & $(2.03)$ & $(1.53)$ & $(1.48)$ \\
\hline \multirow[t]{2}{*}{ DEMOC } & & & & & & -3.35 & $-9.39 * *$ \\
\hline & & & & & & $(-0.92)$ & $(-2.39)$ \\
\hline \multirow[t]{2}{*}{ EXCONS } & & & & & & & $-17.81^{* *}$ \\
\hline & & & & & & & $(-2.07)$ \\
\hline \multirow[t]{2}{*}{ AZTOCR } & & & & & & & -23.28 \\
\hline & & & & & & & $(-1.64)$ \\
\hline \multirow[t]{2}{*}{ POLRIGHTS } & & & & & & & 22.59 \\
\hline & & & & & & & $(-)$ \\
\hline \multirow[t]{2}{*}{ CIVLIB } & & & & & & & 4.52 \\
\hline & & & & & & & (1.59) \\
\hline \multirow{2}{*}{ LAG } & & $5.21^{* * * *}$ & $5.28^{* * *}$ & $5.34^{* * *}$ & $3.28^{* * *}$ & $3.45^{* * *}$ & $6.11^{* * *}$ \\
\hline & & $(5.09)$ & $(4.89)$ & $(4.58)$ & (2.68) & $(4.21)$ & $(3.51)$ \\
\hline \multirow[t]{2}{*}{ CONST } & $-17.41^{* * *}$ & $-22.87^{* * *}$ & -17.24 & -14.80 & -8.90 & -13.74 & $-56.63^{* *}$ \\
\hline & $(-4.60)$ & $(-2.88)$ & $(-1.44)$ & $(-1.23)$ & $(-0.71)$ & $(-0.87)$ & $(-2.17)$ \\
\hline Pseudo- $R^{2}$ & 0.42 & 0.75 & 0.76 & 0.76 & 0.81 & 0.82 & 0.89 \\
\hline Observations & 160 & 160 & 160 & 160 & 160 & 160 & 160 \\
\hline $\mathrm{N}$ & 51 & 51 & 51 & 51 & 51 & 51 & 51 \\
\hline
\end{tabular}

Notes: $z$-values are reported in parentheses. Robust standard errors adjusted for clustering have been employed to compute $z$-statistics. ${ }^{* * *},{ }^{* *}$, and $*$ indicate significance at $1 \%, 5 \%$, and $10 \%$, respectively. 